Published in "Natural Product Research 32 (16): 1971-1976, 2018"

which should be cited to refer to this work.

\title{
Rauvolfianine, a new antimycobacterial glyceroglycolipid and other constituents from Rauvolfia caffra. Sond (Apocynaceae)
}

Robert Ebeh Messanga a, Ngono Bikobo Dominique Serge ${ }^{a, e}$, Auguste Abouem A. Zintchem ${ }^{a, b}$, Mbabi Nyemeck II Norberta, , Moni Ndedi Esther Del Florenced, Betote Diboué Patrick Hervéd, Nyegue Maximilienne Ascension ${ }^{d}$, Atchadé Alex De Théodore ${ }^{\text {, }}$ Pegnyemb Dieudonné Emmanuela ${ }^{a}$, Bochet Christian G. ${ }^{e}$ and Ulrich Koert ${ }^{c}$

aFaculty of Science, Department of Organic Chemistry, University of Yaoundé I, Yaoundé, Cameroon; ${ }^{b}$ Department of Chemistry, Higher Training College, University of Yaoundé I, Yaoundé, Cameroon; 'Faculty of Chemistry, Philipps-Universität Marburg, Marburg, Germany; 'Faculty of Science, Department of Microbiology, University of Yaoundé I, Yaoundé, Cameroon; 'Department Chemie, Universität Fribourg, Fribourg, Switzerland

\section{ABSTRACT}

The chemical investigation of the extract of the dried leaves of Rauvolfia caffra (Sond) (synonym Rauvolfia macrophylla) (Apocynaceae) led to isolation of a new glycoside derivative, rauvolfianine (1) as well as six known compounds: oleanolic acid (2), sitosterol-3-O- $\beta-D-$ glucopyranoside (3), betulinic acid (4), vellosimine (5), sarpagine (6) and D-fructofuranosyl- $\beta$-( $2 \rightarrow 1)$ - $\alpha$-D-glucopyranoside (7). Compounds $\mathbf{1}, \mathbf{2}, \mathbf{3}, \mathbf{4}$ and $\mathbf{7}$ were evaluated for antitubercular activity. Compounds 1 and 2 were the most active ( $\mathrm{MIC}=7.8125$ and $31.25 \mu \mathrm{g} / \mathrm{mL}$ ) towards the Isoniazid resistant strain of Mycobacterium tuberculosis AC45. Their structures and relative stereochemistry were elucidated by spectroscopic methods.

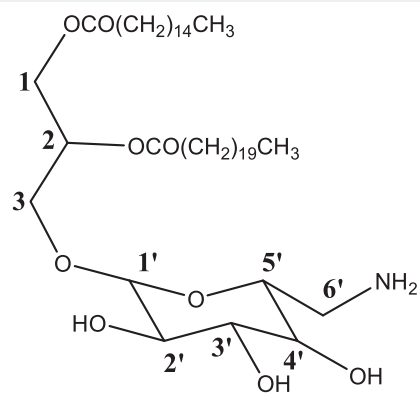

Rauvolfianine (1)

\section{KEYWORDS}

Rauvolfia caffra;

Apocynaceae; Rauvolfianine;

glycerol ester; 1D and 2D

NMR; antitubercular activity

CONTACT Ngono Bikobo Dominique Serge ngono_serge@yahoo.fr

(4) Supplemental data for this article can be accessed at https://doi.org/10.1080/14786419.2017.1356832. 


\section{Introduction}

Tuberculosis is a chronic contagious disease caused by numerous species of Mycobacterium. The number of patients infected with the disease is rising worldwide. In addition, the highest mortality through co-infection with HIV/AIDS and the emergence of bacilli multi-resistant to antibiotics aggravates the impact of this disease especially in African continent (WHO 2014). Furthermore, the majority of Mycobacterium species are resistant to the most widely used therapeutic agents in the treatment of tuberculosis (isoniazid) (van Ingen 2015). Thus, there is an urgent need for new efficient antimycobacterial agents to replace those currently in use. Therefore, plant kingdom represents undoubtedly an untapped reservoir of novel drugs and alternate available medications or herbal remedies (Luo et al. 2011). Rauvolfia caffra which is a tree up to $25 \mathrm{~m}$ high, occurring in habitats of tropical forest zone of Cameroon and Nigeria (Burkill 1985). This species and others have been used in folk medicine to cure various ailments and infectious diseases (Mabberley 2008; Jain 2016; Kumar et al. 2016). The roots of $R$. caffra enter into treatment of intestinal worms, syphilis, as vermifuge and to cure venereal diseases (Walker-Raponda and Sillans 1961). Screening of literature revealed that, $R$. caffra, has been previously investigated for its chemical constituents. However, among the various phytochemicals identified to occur in this plant and other species of Rauvolfia genus, mainly alkaloids especially indole alkaloids along with phenols, flavonoids and tannins were detected in large amounts (Amer and Court 1981; O'Connor and Maresh 2006; Deshmukh et al. 2012; Jamkhande et al. 2013). R. caffra has not been investigated for antitubercular activity. Hence, this study was carried out to evaluate the potent bioactive constituents with antitubercular activity.

\section{Results and discussion}

By comparison of their spectral data with that reported in the literature compounds 2-7 (Figure 1) were identified as oleanolic acid (2) (Higuchi et al. 2008), sitosterol-3-O- $\beta$-D-glucopyranoside (3) (Ngono Bikobo et al. 2014), betulinic acid (4) (Sani et al. 2011), vellosimine (5), sarpagine (6) (Amer and Court 1981) and D-fructofuranosyl- $\beta-(2 \rightarrow 1)$ - $\alpha$-D-glucopyranoside (7) (Yamamori et al. 2017).

\subsection{Identification of compound 1}

Compound 1 was obtained as a white amorphous powder $[\alpha]_{D}^{25}=-5.1^{\circ}(c=0.10, \mathrm{MeOH})$ and displayed a molecular ion at $\mathrm{m} / \mathrm{z} 807.7[\mathrm{M}+\mathrm{Li}+\mathrm{H}]^{+}, 823.7[\mathrm{M}+\mathrm{Na}+\mathrm{H}]^{+}$and 839.7 $\left[\mathrm{M}+\mathrm{K}+\mathrm{H}^{+}\right.$(calcd for $807.69,823.67$ and 839.68 , respectively) that was determined by ESI-MS (Figure S2) corresponding to the formula $\mathrm{C}_{46} \mathrm{H}_{89} \mathrm{NO}_{9}$. The IR spectrum (Figure S3) showed bands at $3412 \mathrm{~cm}^{-1}$ due to amino group, 1728 and $1639 \mathrm{~cm}^{-1}$ for ester carbonyl absorptions and 1058 and $1039 \mathrm{~cm}^{-1}$ for C-O-C absorptions. Correlations on 2D-NMR (HMBC) spectra between numerous aliphatic carbons $\left(\delta_{c} 28.7-33.2\right)$ with common aliphatic protons $\left(\delta_{\mathrm{H}} 1.24-2.32\right)$ indicated the presence of a long saturated alkyl chain (Table S1). The ${ }^{1} \mathrm{H}$ NMR spectrum (Figure S4) of 1 indicated the presence of two methyl signals at $\delta_{\mathrm{H}} 0.84(6 \mathrm{H}$, $t, J=6.5 \mathrm{~Hz}, \mathrm{CH}_{3}-16^{\prime \prime \prime}$ and $\left.21^{\prime \prime}\right)$ and methylene groups at $\delta_{\mathrm{H}} 1.24(58 \times \mathrm{H}$, brs) and $1.48(4 \mathrm{H}$, $m, J=6.70 \mathrm{~Hz}$ ). Besides these methylene groups, there was also signal originating from two methylene protons adjacent to carbonyl carbon atoms at $\delta_{\mathrm{H}} 2.25(2 \mathrm{H}, t, J=2.3 ; 7.3,14.7 \mathrm{~Hz}$, 
$\left.\mathrm{H}-2^{\prime \prime \prime}\right)$ and $2.29\left(2 \mathrm{H}, t, J=2.3 ; 7.3 \mathrm{~Hz}, \mathrm{H}-2^{\prime \prime}\right)$. This was supported by the presence of two carbonyl carbon signals of the two fatty ester groups at $\delta_{C} 172.1\left(\mathrm{C}-1^{\prime \prime}\right)$ and $172.2\left(\mathrm{C}-1^{\prime \prime \prime}\right)$. The HMBC cross peaks of the latters with the carbon atoms corresponding to the carbonyl aforementioned allowed us to assume these two saturated alkyl chain moiety to be attached to the quaternary carbon atoms at $\delta_{C} 172.2$ and 172.1 , respectively. In addition, two primary alcohols were noticeable at $\delta_{C} 62.3$ and 64.3 [linked, in HSQC (Figure S7) to the protons at $\delta_{\mathrm{H}} 4.34 / 4.14$ and $3.89 / 3.39$, respectively] as well as a secondary one at $\delta_{\mathrm{C}} 69.4\left(\delta_{\mathrm{H}} 5.13, \mathrm{H}-2\right)$; those data were in good agreement with a glyceroyl moiety substituted by saturated alkyl chain. Moreover, a glucopyranosyl moiety was indicated by the signal of the anomeric proton at $\delta_{\mathrm{H}} 4.40\left(\mathrm{~d}, J=3.9 \mathrm{~Hz}, \mathrm{H}-1^{\prime}\right)$ and in agreement with carbon signals at $\delta_{\mathrm{C}} 98.0\left(\mathrm{C}-1^{\prime}\right)$, $74.1\left(\mathrm{C}-4^{\prime}\right), 72.6\left(\mathrm{C}-3^{\prime}\right), 71.3\left(\mathrm{C}-2^{\prime}\right), 68.2\left(\mathrm{C}-5^{\prime}\right)$ and $54.4\left(\mathrm{C}-6^{\prime}\right)$. Therefore, compound 1 was deduced to be a glyceroglycolipid (He et al. 2006; Tebou et al. 2016). The ${ }^{13} \mathrm{C}$ NMR spectrum (Figure S5) revealed characteristic signals of aminosugar (He et al. 2006) in which the C-6' signal appeared in upfield shift at $\delta_{C}$ 54.4. The correlations between $\mathrm{H}-1\left(\delta_{\mathrm{H}} 4.14\right)$ and $\mathrm{H}-2$ $\left(\delta_{H} 5.13\right)$ to $C-1{ }^{\prime \prime \prime}\left(\delta_{C} 172.2\right)$ and $C-1{ }^{\prime \prime}\left(\delta_{C} 172.1\right)$, respectively, observed in HMBC suggested the attachment of two fatty acid ester groups in position- 1 and 2 of the glycerol moiety. Thus, 1 was determined to be a diacylglycerylaminoglucopyranoside. This was strengthened by the HMBC (Figure $\mathrm{S} 8$ ) cross peaks of the anomeric proton $\delta_{\mathrm{H}} 4.40\left(\mathrm{H}-1^{\prime}\right)$ with carbon atom at 64.3 (C-3) indicating the aminosugar unit to be attached in position-3 of the glycerol moiety. The ${ }^{1} \mathrm{H}$ and ${ }^{13} \mathrm{C}$ NMR spectra of compound 1 were very similar to those observed for rouremin (He et al. 2006). The difference was provided by the presence of one more methylene group in $\mathbf{1}$, observation supported by the ESI-MS data of $\mathbf{1}$ corresponding to 14 a.m.u. greater than rouremin. The length of two fatty acid ester chains of compound $\mathbf{1}$ were determined on the basis of ESI-MS spectrum and in comparison with literature data (He et al. 2006). Therefore, these two fatty acid chains were deduced to be a palmitoyl and heneicosanoyl groups which were attached at C-1 and C-2, respectively as described above. The relative configuration of carbon $\mathrm{C}-2$ was determined from coupling constants of $\mathrm{H}-2$, $\mathrm{H}-1$ and $\mathrm{H}-3$ protons and from NOESY results (Figure S9). The observation of 9.2, 10.0 and $10.6 \mathrm{~Hz}$ values of protons $\mathrm{H}-1\left(\delta_{\mathrm{H}} 4.34\right), \mathrm{H}-2\left(\delta_{\mathrm{H}} 5.13\right)$ and $\mathrm{H}-3\left(\delta_{\mathrm{H}} 3.89\right)$, respectively suggested the trans-relationships of these protons. The NOESY correlation observed between $\mathrm{H}-2\left(\delta_{\mathrm{H}} 5.13\right)$ and $\mathrm{H}-3\left(\delta_{\mathrm{H}} 3.39\right)$ and this latter and $\mathrm{H}^{\prime}-1\left(\delta_{\mathrm{H}} 4.40\right)$ indicated the common orientation on the same side of the molecule for these protons. The structure of $\mathbf{1}$ was, therefore, established as (2S*)-1-O-palmitoyl- $\beta$-O-heneicosanoyl-3-O-(6-amino-6-deoxy)$\beta$-D-glucopyranosylglycerol named rauvolfianine. According to Cantrell et al. (2001), isolated compounds that display a MIC of $64 \mu \mathrm{g} / \mathrm{mL}$ or lower are considered promising. For extracts, the MIC should be equal to or lower than $125 \mu \mathrm{g} / \mathrm{mL}$. Thus, the values of $62.5 \mu \mathrm{g} / \mathrm{mL}$ for compounds $\mathbf{3}$ and $\mathbf{4}$, and of $31.25 \mu \mathrm{g} / \mathrm{mL}$ as previously reported (Gu et al. 2004) for $\mathbf{2}$, obtained here, are as good as a promising isolated compound. Compound $\mathbf{1}$ which had a minimal inhibitory concentration (MIC) of $7.8125 \mu \mathrm{g} / \mathrm{mL}$, showed stronger antitubercular activity than other compounds. This might be explained by the susceptibility of less polar compounds to lipid hydrophobic cell of mycobacteria (Pauli et al. 2005; Chraibi et al. 2016). Although the MIC values obtained here are larger than that of Ripamficin $(0.976 \mu \mathrm{g} / \mathrm{mL})$, these inhibitory concentrations are comparable to the MIC of pyrazinamide (another firstline antitubercular drug), $20-100 \mu \mathrm{g} / \mathrm{mL}$ (Higuchi et al. 2008). Regarding the MBC values of all tested compounds (Table 2S) it seems that they could be similar to their MIC values against the isolate strain (AC45). According to Pankey and Sabath (2004) bacteriostatic 


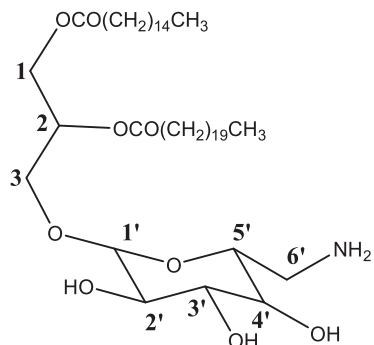

Rauvolfianine (1)
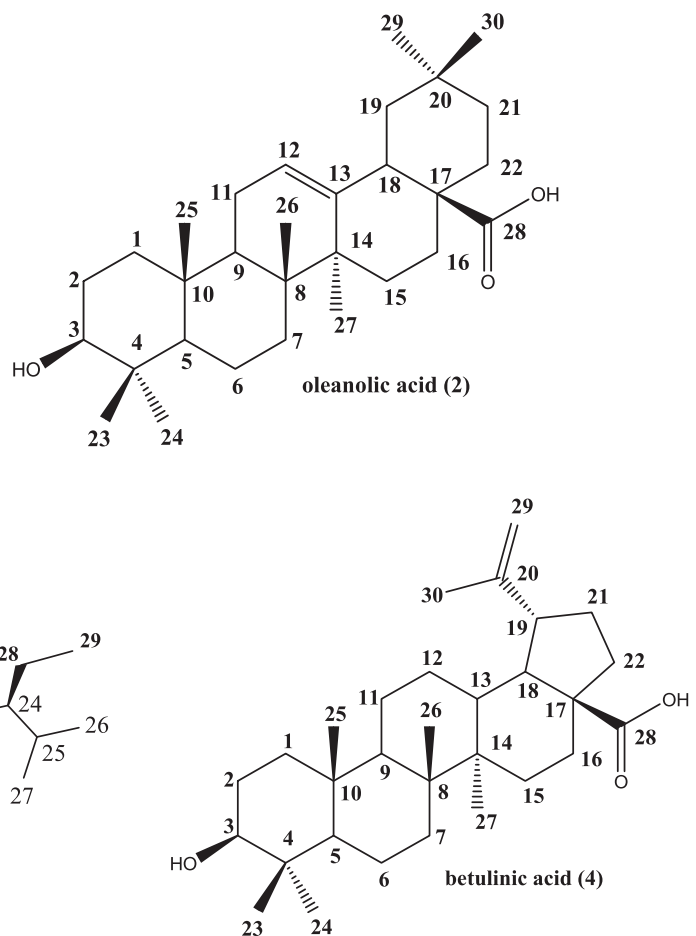

sitosterol-3-O- $\beta$-D-glucopyranoside (3)

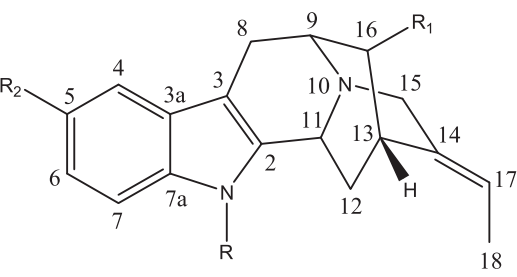

$\mathbf{R}=$ Me, $\mathbf{R}_{1}=\mathrm{CHO}, \mathbf{R}_{\mathbf{2}}=\mathbf{H}$; (+)-vellosimine (5)

$\mathrm{R}=\mathrm{H}, \mathrm{R}_{1}=\mathrm{CH}_{2} \mathrm{OH}, \mathrm{R}_{2}=\mathrm{OH}$; sarpagine (6)

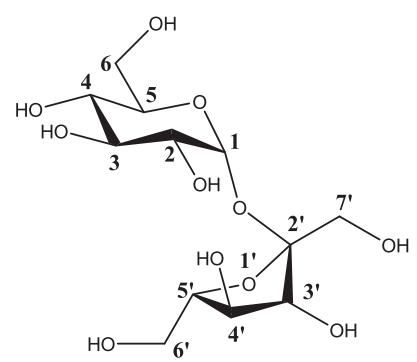

D-fructofuranosyl- $\beta-(2 \rightarrow 1)-\alpha$-D-glucopyranoside (7)

Figure 1. Compounds isolated from the leaves of Rauvolfia caffra.

activity has been defined as a ratio of MBC to MIC of > 4. Thus, all tested compounds exhibited bactericidal action against the studied strain.

\section{Experimental section}

In supplemental data.

\section{Conclusion}

The species $R$. caffra, is known as abundant source of alkaloids especially indole alkaloids. Compounds 1, 2, 3 and $\mathbf{7}$ were isolated for the first time from this species. The bioactivity 
study of the isolated compounds indicated that compounds $\mathbf{1}$ and $\mathbf{2}$ exhibited interesting antitubercular activity.

\section{Acknowledgements}

We also thank the DAAD / STIBET Doktoranden Scholarship for financial support and travel grants for Mr. Mbabi to Germany. We thank Mr. V. Nana for the collection and identification of plant material. We thank Mr. Felix Fehr of Department of Chemistry of University of Fribourg and Koert's team of PhilippsUniversität Marburg for spectral analysis.

\section{Disclosure statement}

No potential conflict of interest was reported by the authors.

\section{Funding}

The authors gratefully acknowledge financial support from the Swiss National Science Foundation (SNSF) [grant number IZK0Z2-157272] for research fellowships in Switzerland to D. S. Ngono Bikobo.

\section{References}

Amer MMA, Court WE. 1981. Root wood alkaloids of Rauwolfia macrophylla. Planta med. 43(1):94-95. Burkill HM. 1985. The useful plants of West Tropical Africa. 2nd ed. Vol. 1, Families A- D. Kew, Richmond: Royal Botanic Gardens.

Cantrell CL, Franzblau SG, Fischer NH. 2001. Antimycobacterial plant terpenoids. Plant Med. 67(08):685694.

Chraibi M, Farah A, Lebrazi S, El Amine O, Mohammed Iraqui Houssaini MI, Fikri-Benbrahim K. 2016. Antimycobacterial natural products from Moroccan medicinal plants: chemical composition, bacteriostatic and bactericidal profile of Thymus satureioides and Mentha pulegium essential oils. Asian Pac J Trop Biomed. 6(10):836-840.

Deshmukh SR, Dhanashree SA, Patil BA. 2012. Extraction and evaluation of indole alkaloids from Rauvolfia serpentina for their antimicrobial and antiproliferative activities. Int J Pharm Pharmac Sci. 4(5):329-334.

Gu JQ, Wang Y, Franzblau SG, Montenegro G, Yang D, Timmermann BN. 2004. Antitubercular constituents of Valeriana laxiflora. Planta Med. 70:509-514.

He DZ, Ma CY, Tan GT, Sydara K, Tamez PA, Southavong B, Bouamanivong S, Soejarto DD, Pezzuto JM, Fong HHS, et al. 2006. Rourinoside and rouremin, antimalarial constituents from Rourea minor. Phytochemistry. 67:1378-1384.

Higuchi CT, Sannomiya M, Roberto S, Sacramento LVS, Sato DN. 2008. Triterpenes and anti-tubercular activity of Byrsonima crassa. Quim Nova. 31(7): 1719-1721.

van Ingen J. 2015. Microbiological diagnosis of nontuberculous mycobacterial pulmonary disease. Clin Chest Med. 36(1):43-54.

Jain P. 2016. Secondary metabolites for antiulcer activity. Nat Prod Res. 30(6):640-656.

Jamkhande PG, Barde SR, Patwekar SL, Tidke PS. 2013. Plant profile, phytochemistry and pharmacology of Cordia dichotoma (Indian cherry): a review. As Pac J Trop Biomed. 3(12):1009-1012.

Kumar S, Singh A, Bajpai V, Srivastava M, Singh BP, Kumar B. 2016. Strutural characterization of monoterpene indole alkaloids in ethanolic extracts of Rauwolfia species by liquid chromatography with quadrupole time-of-flight mass spectrometry. J Pharm Anal. 6(6):363-373.

Luo X, Pires D, Aínsa JA, Gracia B, Mulhovo S, Duarte A, Anes A, Ferreira MJ. 2011. Antimycobacterial evaluation and preliminary phytochemical investigation of selected medicinal plants traditionally used in Mozambique. J Ethnopharmacol. 137(1):114-120. 
Mabberley DJ. 2008. Mabberley's plant-book: a portable dictionary of plants. Their classifications and uses. London: Cambridge University Press.

Ngono Bikobo DS, Mosset P, Abouem ZA, Atchadé AT, Balemaken Missi M, Mbabi Nyemeck II N, Pegnyemb DE. 2014. Campylospermine, an N-hydroxy alkaloid from the leaves of Campylospermum densiflorum (Ochnaceae). Int J Pharm Phyt Res. 6:719-728.

O'Connor SE, Maresh JJ. 2006. Chemistry and biology of monoterpene indole alkaloid biosynthesis. Nat Prod Rep. 23:532-547.

Pankey GA, Sabath LD. 2004. Clinical relevance of bacteriostatic versus bactericidal mechanisms of action in the treatment of gram- positive bacterial infections. Clin Infect Dis. 38:864-870.

Pauli GF, Case RJ, Inui T, Wang Y, Cho S, Fischer NH, Franzblau SG. 2005. New perspectives on natural products in TB drug research. Life Sci. 78:485-494.

Sani AA, Rafat OA, Sikirat AS, Alemika TE, llyas M. 2011. Structure determination of betulinic acid from the leaves of Lophira lanceolata Van Tiegh. Ex Keay (Ochnaceae). J App pharmac sci. 8:244-245.

Tebou FPL, Mabou FD, Ngnokam D, Harakat D, Voutquenne-Nazabadioko L. 2016. Owariensisone: a new iridolactone from the whole plant of Brillantaisia owariensis P. Beauv Nat Prod Res. 30:1611-1616.

Walker-Raponda A, Sillans R. 1961. Les plantes utiles du Gabon. Paris: Paul Lechevalier; p. 614.

World Health Organization. 2014. Global tuberculosis report 2014. Geneva:World Health Organization. [cited 2015 Dec 15]. https://www.who.int/tb/publications/global_report/gtbr14_main_text.pdf

Yamamori A, Takata Y, Fukushi E, Kawabata J, Okada H, Kawazoe N, Ueno K, Onodera S, Shiomi N. 2017. Strutural analysis of novel low-digestible sucrose Isomers synthesized from D-glucose and D-fructose by thermal treatment. J Appl Glycosci. 64:15-19. 